\title{
Perspectives
}

\section{Sexism in Japanese Radio Business English Program Textbooks}

\section{Sumie Matsuno \\ Aichi Prefectural University}

In Japanese society, "sexism" is still pervasive and has crept into EFL (English as a Foreign Language) textbooks. The Easy Business English series of textbooks, utilized by a nation-wide radio program in Japan from October 2000 to March 2001, are examined for sexism. A brief analysis of the omission of females is followed by a discussion of occupational roles of males and females, and then a discussion of gendered identities. Finally, word choices are investigated. This paper concludes that sexism is still an issue to be dealt with and suggests that EFL teachers reexamine the textbooks used in their classrooms.

日本の社会では現在もなお、性差別（sexism） が存在し、それが英語のテ キストにも反映されている。本研究では全国ネットのラジオ局による語学プ ログラム「やさしいビジネス英語」で2000年10月から2001年3月まで使用され たテキストを取り上げ、性差別の観点から分析した。女性の過少評価の分析か ら始め、男女の役割、男女のアイデンティティ、言語差別等を調査した。その 結果、性差別が存在することを明らかにし、英語教師が教室で使用するテキス トに関しても、性差別の有無を再調査するよう提案している。

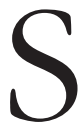

exism is "discrimination on the grounds of sex, based on assumptions that women are both different from and inferior to men" (Talbot, 1998, p. 215). In Japanese society, "sexism" is still widespread; the fact that women continue to have more difficulty in finding jobs than men, as well as the fact that a woman's average salary is about $60 \%$ of a man's salary in a comparable job, suggests the existence of sexism (Kojima, 2000). 
The sexism that exists in Japanese society has crept into our EFL textbooks as well. Even though gendered identities might be transformed in the process of second language socialization (Pavlenko, 2001), and Japanese women may learn English to escape from the identities forced on them by national ideologies, when textbooks incorporate the notion of sexism, studying English may actually reinforce or create beliefs in gender inequality through textbooks. As Renner (1997) stated, "the textbooks used within an EFL setting are not just tools by which the English language is taught. A large dose of cultural content is also present within them" (p. 3). Texts can be sexist "if they omit the actions and achievements of women, if they demean women by using patronizing language, or if they show women only in stereotyped less capable roles" (Graci, 1989, p. 478). The purpose of this paper is to investigate sexism in a mainstream English as a foreign language (EFL) textbooks published in Japan.

Much ink has been devoted to sexism and textbook analyses over the past few decades (e.g., Coles, 1977; Graci, 1989; Gross, 1996; Hellinger, 1980; Holt, 1990; Hommes, 1978; Mannheim, 1995; Peterson \& Kroner, 1992; Porreca, 1984; Potter \& Rosser, 1992; Sadker \& Sadker, 1980; Schmitz, 1975; Siegal \& Okamoto, 1996; Sims, 1997; Stern, 1976; Talansky, 1986; Tietze \& Davis, 1981; Walford, 1981); therefore great strides have been made. However, no research has been done on EFL textbooks published in Japan, where sexism still appears, particularly in those used by business organizations. My question is: Does sexism still exist in EFL textbooks published in Japan? Taking the textbooks of a business English program aired on national radio as examples, I will attempt to answer this question.

\section{Sexism and Textbook Analysis}

Various kinds of textbooks, including EFL textbooks, come within the scope of this literature review. Although some textbook analysts have advocated the use of a feminist perspective (Alvermann \& Commeyras, 1996; Holt, 1990), abundant investigations have shown textbooks to be sexist in various areas. Scholars have found four main areas in which they have detected manifestations of sexism, three of which are related to content and one to language itself.

One manifestation of sexism appearing in textbooks is the omission of females; females do not appear as often as males in texts (Coles, 1977; Hommes, 1978; Sadker \& Sadker, 1980; Schmitz, 1975; Stern, 1976). Porreca (1984), for example, found that the average ratio of females to males in the 15 most widely used ESL textbooks she surveyed, including 
apparent masculine generic constructions, was 1:2.06, and the mean proportion of females to males in illustrations was 1:1.97.

A second type of sexism emerges in occupational roles of males and females in the texts in terms of both type and range of jobs. According to a study by the Mathematics Education Research group (1980), in six primary textbooks and 25 of 31 secondary textbooks of mathematics published in New Zealand, some of the roles traditionally allocated for males were assigned to females; however, those for females were not assigned to males. Hellinger (1980), in a study of 131 passages from English language textbooks, revealed that women were rarely engaged in any demanding, interesting, or successful activities, while male roles represented a broad range of occupational positions. Sims (1997), surveying test banks accompanying 17 management education texts, discovered that female managers were referred to significantly more often by their first names than male managers.

A third manifestation of sexism concerns stereotypical gendered identities for men and women. Four studies provide examples of this type of sexism: Walford's (1981) review of texts of recently published physics textbooks, which indicated that physics was a more male-oriented subject than a female-oriented one; Potter and Rosser's (1992) scrutiny of five seventh-grade life science textbooks that implied that the achievements of women scientists are relatively fewer or of lesser importance than those of men scientists; Peterson and Kroner's (1992) inspection of 27 current textbooks in introductory psychology and 12 for human development courses, which found that females were frequently portrayed in negative and gender-biased ways; and Siegal and Okamoto's (1996) study of five Japanese textbooks, which represented highly stereotypical social norms based on hegemonic ideologies of class, gender, and language.

A fourth category of sexism in textbooks is evident in linguistic analyses, such as the examination of lexical items. Porreca (1984), for example, found that masculine generic constructions were still used extensively in the 15 most widely used ESL textbooks, and attempts to avoid the masculine generic were often incomplete and confusing, even in passages or sentences where the masculine generic could be easily avoided.

Although many publishers, editors, teachers, and students worldwide object to sexist teaching and learning materials (Mannheim, 1995; Sunderland, 1995), this literature review reveals that many textbooks have been found to include some facets of sexism: omission of females, limited occupational roles for females, negative stereotypical identities for females, and preferential linguistic use of masculine generic con- 
structions rather than gender-neutral ones. Moreover, up to the present time there has been no prominent research about possible sexism in EFL textbooks published in Japan. The purpose of this study, therefore, is to see if recent advances in women's rights in Japan have been reflected in EFL textbooks published in this country, especially those used in the business world.

\section{Research Design}

The Easy Business English series of textbooks, utilized by a nationwide radio program in Japan from October 2000 through March 2001 are examined for sexism. This program was selected because it has been broadcast widely for 14 years and therefore has had and continues to have a great influence on learners using this program and its texts.

\section{Materials and Procedures}

Easy Business English is published in Japan each month and written by eight Japanese authors and a number of native English speakers. Each week, eight regular characters discuss one topic. Every year, the contents in the textbooks from April to September are again utilized from October to March. In this study, all model dialogues that appeared in the textbooks are analyzed; the radio listeners encounter "Vignette" (named as "Today's Vignette" and "Short Dialogue" in the textbooks) from Monday to Friday, where the same eight characters converse in turn. In "Listening Challenge" on Friday, different characters, whose faces can be seen in pictures, appear each time. It is important to note that all of the dialogues are written in the book exactly as they are used in the radio program.

Considering types of manifestations of sexism explained above, I begin this study by briefly examining the omission of females. In this section, the numbers of female and male characters and their turn-takings in "Vignette" are counted; then, since these characters talk about some other individuals, the numbers of male and female individuals talked about by them are also calculated; and then in "Listening Challenge," the numbers of male and female characters who appeared in the pictures are calculated. (Since by just reading the transcripts it is sometimes difficult to decide whether a man or woman is talking, only the male or female characters who appeared in the pictures are counted.) This analysis is followed by a discussion of occupational roles of males and females. In this section, the roles of eight regular characters are first explained; after that, the roles of the female and male individuals talked about by 
these eight characters are enumerated and discussed; and then the roles of female and male characters that appeared in "Listening Challenge" are listed and examined. Next, all gender-related identities found in the textbooks are discussed. Finally, word choices are investigated.

\section{Results and Discussion}

\section{Omission of Females}

In "Vignette" sections, four male and four female characters regularly appear. Two male characters and one female character also appear as guests; therefore the numbers of characters appearing in the texts from October to February are almost equal ( 6 males vs. 5 females). When tallying up the number of turns taken among the characters, it emerges that there were 348 male turn-takings versus 337 female turntakings, which at first glance appears quite equitable. However, when counting the individuals that were mentioned in the dialogues produced by these characters, 22 male individuals and 15 female counterparts are found. In the "Listening Challenge" section, counting the numbers of male and female characters appearing in the pictures revealed that there are 39 male roles compared with 7 female roles, which suggests male dominance in the business organization.

\section{Occupational Roles of Males and Females}

Eight regular characters in "Vignette" are first considered. The main character is a Japanese businessman, Hiromi Araki. There are two male managers: Lou Cruise, aged 47, and Ben Leonard, aged 50. Lee Seymour, Gabby Mann, and Camille Renoir are female businesswomen. Sandy Liu is a male worker coming from the Hong Kong office. Mickey Ramirez, 27, is a female worker whose parents emigrated from Puerto Rico. Seymour, Mann, Renoir, and Liu are in their thirties. That is to say, the two managers and the main character are males and the four subordinates are female. This implies that males are more valuable than females.

These eight characters talk about other men and women whose occupational roles vary:

Table 1: Occupational Roles of Males and Females Appearing in the Dialogues of "Vignette" 
Male

Female

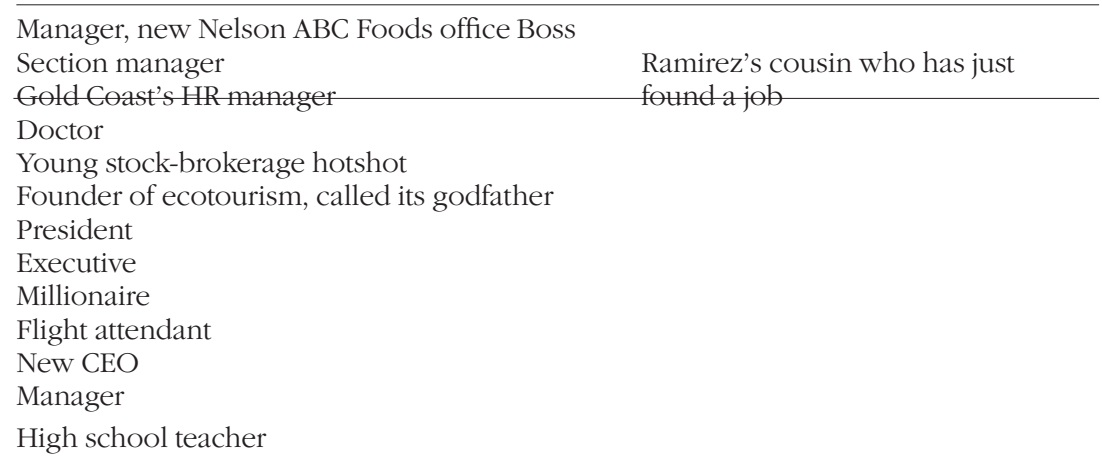

Except for the flight attendant and the high school teacher, all the male roles represent powerful, high status, highly esteemed occupations. Furthermore, although women are mentioned 15 times in the dialogues, only two are mentioned in conjunction with an occupation. Women are often not described in terms of their occupations but rather in terms of their personal relationships, such as mother, cousin, wife, grandmother, and aunt. That esteemed occupational roles are occupied mostly by males and that women are often described in terms of their personal relationships fall under the second category of detecting sexism and gives support to the idea that sexism is present.

In some cases, women could possibly fill the occupational roles in the texts. Although "a doctor" or "doctors," for example, appear nine times in the texts, many of these instances are unclear about whether the person is male or female. Doctors are once referred to as "they" (emphasis added in bold in all examples):

Renoir: $\quad$ Doctors are afraid of being sued if they give more than minimal doses of drugs for pain relief. If they give as much as a patient really needs, death may come faster and then the doctor may be accused of malpractice. (Jan., p. 36)

Cases such as this, in which the referents were inexplicit with regard to gender, were not included in this study.

On the other hand, on the two occasions when a doctor was referred to in the singular form, the doctor was referred to as male. There were no instances of explicitly female doctors. Consider the following ex- 
cerpts.

Mann: I'll let our doctor do the diagnosis. So far, Alissa says she hasn't got a problem, so why go to the doctor? But it's obvious that she needs professional help. I hope he convinces her there's no need to go to extremes. (Oct., p. 58)

Mann: $\quad$ Thank heavens my mother saw the light in time. Her doctor also advised her to think about the right kind of nutrition beginning right now. He pointed out that food figures in cancer too. (Dec., p. 88)

These examples show how doctors are referred to as male.

As far as "Listening Challenge" is concerned, here is a list of the men's and women's occupational roles:

\section{Table 2: Occupational Roles of Males and Females Appearing in "Listening Challenge"}

Male

Female

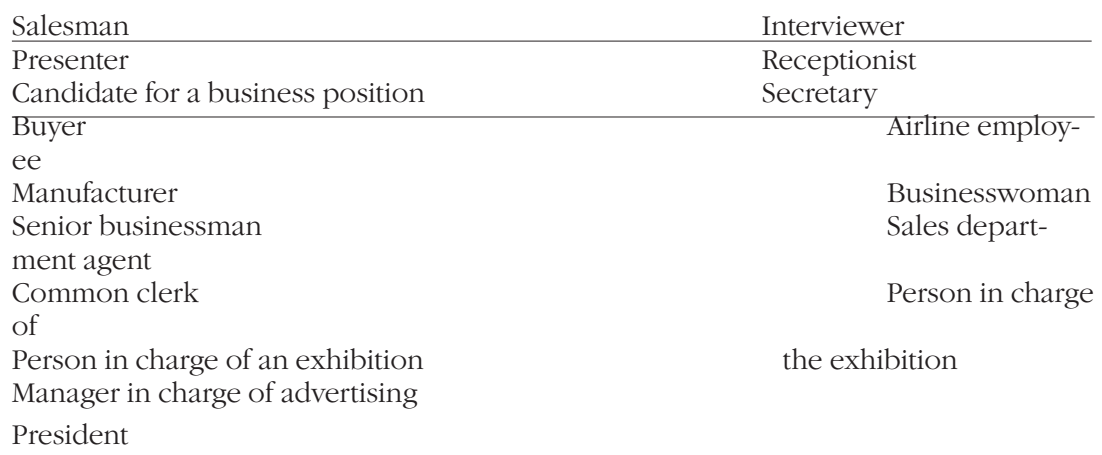

Table 2 indicates that the two highest positions, the manager in charge of advertising and the president, are jobs for males, whereas among the lowest, receptionist and secretary are still solely "female" jobs.

\section{Gendered Identities}

The dialogues in the textbooks produce or reproduce five main gendered sexist identities, visible in the content. The first gendered sexist identity is related to the participants' family organizations. All of 
the following sentences are observed from each participant's dialogue regarding their own family or partner.

Leonard (male): Overall, I've been impressed by my boy's teachers. (Oct., p. 98)

My son spent a lot of time rapping with his favorites. (Oct., p. 98)

My wife gets an annual checkup. (Dec., p. 84)

Liu (male): $\quad$ My wife and I are converts too. (Nov., p. 32)

My son told me that whole floors of his dormitory have monitors. (Dec., p. 24)

Araki (male): $\quad$ Atsuko (his wife) is making money out of online ads. (Dec., p. 16)

... Atsuko gets a percentage of the purchase price. (Dec., p. 16)

Atsuko's gotten so many people involved... (Dec., p.20)

We visited Panama with the kids last year ... (Dec., p. 32)

The kids wanted to pick flowers to press for picture albums. (Dec., p. 44)

My mother said once she doesn't mind dying ... (Jan., p. 32)

Cruise (male): $\quad$ My boys are into that too. (Oct., p. 16)

At first my boys were sending ads around as a duo. (Oct., p. 16)

Mrs. Cruise would do that too. (Feb., p. 108)

108)

Our boys are a different story. (Feb., p.

Mann (female): It's my daughter. Alissa ...(Oct., p. 58)

My parents and Alissa agreed ... (Dec.,

Alissa was very nervous ... (Dec., p.

He asked me out. I said O.K. It's not serious yet, but it feels so good to have a nice guy courting me. (Feb., p. 104)

p. 104)

Alissa gets e-mail valentine cards ... (Feb., 
Seymour (female): Barry (her husband) and I spent part of our honeymoon in Panama. (Dec., p. 32)

grandmother. (Nov., p. 104) ... in spite of some problems with Barry's Barry found a hotel ...(Nov., p. 104)

Barry took care of all that ... (Nov., p.

Barry had to canvass hotels (Nov., p. know. (Nov., p. 108)

Barry's mother got in touch with ...(Nov.,

I'll make a note of that and let Barry

I'll shoot a memo to Barry... (Nov., p. 112)

Barry and I might want to follow in your footsteps. (Dec., p. 36)

Barry won't book an ecotour. (Dec., p. investment. (Jan., p. 36)

Barry's father bought it as part of an

Even Barry was flabbergasted, ... (Feb., 92

Ramirez (female): Rodrigo (her husband) and I value our time at home together. (Dec., p. 60)

Rodrigo calls it feeling the Christmas spirit every week of the year. (Nov., p. 68)

Renoir (female): Emile (her boyfriend) and I treat each other to ... (Feb., p. 108)

As seen in these statements, Araki, Cruise, Leonard, and Liu are married and have children (three with sons and one with gender-inexplicit "kids"). Seymour and Ramirez are married, but neither appears to have any children. Mann has a daughter but is either single or divorced, since she has a boyfriend (no mention of husband or father of the child). Renoir has a boyfriend. The basic pattern is that women in the business organization are often single or, if married, they have no children.

In addition, from the above sentences, we can note a curious feature: When Leonard and Liu refer to their wives, they utilize the word "wife," 
or on one occasion, Cruise says "Mrs. Cruise," all of which are translated as "tsuma" (wife) in Japanese; these words imply that women are in subordinate roles to men; whereas when the women mention their husbands, they always state their husbands' names and never refer to them as "my husband." Interestingly, when Araki refers to his wife, conversely, he utilizes her name. This may be related to the fact that Atsuko has her own job, which may represent her independence. In contrast, the other three men do not mention their wives' jobs in the texts; therefore it is not clear whether they have their own jobs or not.

The second gendered sexist identity concerns appearance as a women's issue. Consider the following extracts:

$\begin{array}{ll}\text { Renoir: } & \text { I thought you said she finished her computer-training } \\ \text { course with flying colors. } \\ \text { Ramirez: } \\ \text { She did. I wasn't worried about her skills. I was con- } \\ \text { cerned about her appearance. She didn't have the } \\ \text { proper clothing to look good for a job interview. (Nov., } \\ \text { p. 8) }\end{array}$

Ramirez's comment conveys the importance of a female interviewee's appearance rather than her skills. This notion creates specific gendered identity, and may induce the radio listeners to accept this identity.

Furthermore, women are stereotypically represented as being concerned with appearance irrespective of their age, situation, or business position. A girl is anxious about her appearance.

Mann:

...It's my daughter. Alissa is obsessed with her weight and shape. She eats little and doesn't keep it down. Her weight loss is obvious, but she still feels fat even though she's underweight. (Oct., p. 58)

Mentioning her daughter, Mann may have created an image of girls who care too much about their appearance. The text introduces the slogan "Don't Weigh Your Self-Esteem ... It's What's Inside That Counts" (Oct., p. 77). This text can help to produce the image of women who consider their appearance more important than their talents, skills, or education. However, anorexia is in fact a problem that real women face and is taken very seriously by most feminists. This might therefore be seen as positive recognition of a women's issue.

The third gendered sexist identity concerns prioritizing family choices over business. Here is Wenz's case:

Wenz (female): I left M \& B to get married and came back this week 
after my divorce.
Araki: I'm sorry things didn't work out for you. (Jan, p. 8)

This example reveals that for a woman, getting married often means giving up her career and choosing homemaking. Wenz's statement contributes to a negative image of women. Also, Araki's sympathetic response implies that the return to work might not be perceived as a positive outcome.

Moreover, Leonard talked about millionaires' wives:

Leonard: I thought it was interesting that even these days half the wives don't work outside the home. If they do, they're usually teachers. (Feb., p. 80)

The above excerpt shows that a large number of millionaires' wives work outside the home as teachers; however, it also implies that if women are married to money and are not teachers, they do not work outside the home.

The fourth gendered sexist identity presents women as less valued than males (or wives as less than husbands).

Seymour: Divorce alone is not a complete cure, though. More than half of battered women feel they must have done something deeply wrong to deserve such violence. They blame themselves and often need counseling. (Jan., p. 16)

Seymour's quote somehow describes divorce as something that occurs to women, especially women who are battered. Women need counseling but men are not presented as needing counseling.

That wives' are less valued than husbands also emerges in the following extracts from the dialogues:

Leonard: Divorcing his wife to wed his secretary caused bad vibes in the company's local community. That invited a lot of boos and catcalls.

Seymour: Other CEOs have done that and survived. (Jan., p. 80)

This suggests that husbands can have affairs; on the other hand, no wives' affairs are presented in the textbooks. The wives are portrayed as being divorced and being on the outside; if they had endured in silence then maybe they would still be married. 
The fifth gendered sexist identity concerns the fact that disabled, sick, and elderly people, who are regarded as weaker than ordinary people, are almost always portrayed as women. This trend is illustrated in the following dialogue samples:

Seymour: We had a fine time, in spite of some problems with Barry's grandmother. She has Parkinson's disease and has to travel in a wheelchair. (Nov., p. 104)

Renoir: $\quad$ Once a wheelchair traveler told me she didn't want to be treated with kid gloves. (Nov., p. 112)

Mann: $\quad$...my mother hadn't seen a doctor for years. Her skin-care consultant, who makes a house call once a month, has been urging her for a long time to have a mammogram. Well, finally my mother did just that. She tested positive. She has breast cancer. (Dec., p. 80)

Leonard: Well, you all know my Aunt Etta. She collapsed at dinner last night and had to be hospitalized. We knew she had colon cancer... (Jan., p. 32)

Since no man appears sick or disabled in the texts, the effect is the creation of gendered images of weak, ill, or disabled elderly women.

\section{Word Choice}

Manifestations of sexism are also found in the word choices. Consider the following sexist use of language:

One man's meat is another man's poison.

Americans dip into their pockets and do something about it, whether we're talking victims of natural disasters or man-made atrocities.

Why are Mr. and Mrs. Average American still limping along from one paycheck to the next?

On the other hand, the texts also at times carefully use words in a gender-neutral fashion:

In most cases, there are warning signs that a coworker is going to blow his or her top.

The campaign's aimed mainly at homemakers...

The passenger sees this humongous furry spider right next to his or her face. 
If somebody goes too far, take him or her aside and talk it over quietly.

Though the word "homemakers" is translated into "shufu (housewife)" in Japanese transcripts, the word choice of "homemakers" shows an attempt to eradicate sexism.

Overall, both sexist and nonsexist language in the texts can be seen. The usage of gender-neutral pronouns in some sections and male pronouns in other sections may be due to a schizophrenic pull among the eight different authors.

\section{Conclusion}

Learning English is a situation where learners are socialized into the target culture, and many Japanese women may learn English hoping to get rid of their gendered identities forced on them by national ideologies. A radio language program, an excellent device for learning a language, has the power to shape the listener's ideas. This paper cites examples of various aspects of sexism in the Easy Business English textbooks, demonstrating that sexism is still an issue to be dealt with.

More research is necessary to see if these examples of sexism are part of a broader trend in Japanese EFL textbooks. Furthermore, not only should textbook writers and publishers make great efforts to eliminate sexism when creating textbooks, but also we as EFL teachers should reexamine textbooks used in classrooms as well as those intended for private study before actually utilizing them as teaching materials in order to evaluate how gendered identities are treated in their contents, both on the surface and in substance.

\section{Acknowledgements}

I wish to thank Dr. Gabriele Kasper, who gave me the idea to write this paper, and the anonymous reviewers of the JALT Journal for their insightful comments and time spent for me. I also want to express my appreciation to Charla Waity who always helps me edit my papers.

Sumie Matsuno is a lecturer at Aichi Prefectural University, Aichi Sangyou University College, and Nagoya College of Foreign Languages. She obtained a MA degree at Colorado State University and is now a doctoral candidate at Temple University Japan. Her interests include gendered identities, motivation, and testing. 


\section{References}

Alvermann, D. E., \& Commeyras, M. (1996). Gender, text, and discussion: Expanding the possibilities. In R. Garner \& A. A. Patricia (Eds.), Beliefs about text and instruction with text. Hillsdale, NJ: Erlbaum.

Coles, G. S. (1977). Dick and Jane grow up: Ideology in adult basic education readers. Urban Education, 12, 37-53.

Easy business English (October, 2000). Tokyo: Nihon housou kyoukai.

Easy business English (November, 2000). Tokyo: Nihon housou kyoukai.

Easy business English (December, 2000). Tokyo: Nihon housou kyoukai.

Easy business English (January, 2001). Tokyo: Nihon housou kyoukai.

Easy business English (February, 2001). Tokyo: Nihon housou kyoukai.

Easy business English (March, 2001). Tokyo: Nihon housou kyoukai.

Graci, J. P. (1989). Are foreign language textbooks sexist? An exploration of modes of evaluation. Foreign Language Annals, 22, 477-486.

Gross, G. (1996). Weaving girls into the curriculum. Paper presented at the annual meeting of the American Association of Colleges for Teacher Education, Chicago.

Hellinger, M. (1980). For men must work, and women must weep: Sexism in English language textbooks used in German schools. In C. Kramarae (Ed.), The voices and words of women and men (pp. 267-274). Elmsford, NY: Pergamon Press.

Holt, E. R. (1990). Remember the ladies - women in the curriculum. (ERIC Document Reproduction Service No. ED319652)

Hommes, E. W. (1978). Sexism in high school literature anthologies. Unpublished doctoral dissertation, Georgia State University.

Kojima, T. (2000). Imidas. Tokyo: Syueisha.

Mannheim, C. (1995). The boss was called Mr. Power: earners' perspectives on sexism in EFL materials. In J. Sunderland (Ed.), Exploring gender: Questions and implications for English language education, (pp. 83-89). London: Prentice Hall International.

Mathematics Education Research. (1980). Sex-role stereotyping in mathematics textbooks. (ERIC Document Reproduction Service No. ED212467)

Pavlenko, A. (2001). Bilingualism, gender, and ideology. The International Journal of Bilingualism, 5, 117-151.

Peterson, S. B., \& Kroner, T. (1992). Gender biases in textbooks for introductory psychology and human development. Psychology of Women Quarterly, 16, 17-36.

Porreca, K. (1984). Sexism in current English textbooks. TESOL Quarterly, 18, 705-725.

Potter, E. F., \& Rosser, S. V. (1992). Factors in life science textbooks that may 
deter girls' interest in science. Journal of Research in Science Teaching, 29, 669-686.

Renner, C. (1997). Women are "busy, tall, and beautiful": Looking at sexism in EFL materials. Paper presented at the National Seminar: "Mind the Language" (Rome, Italy, November 15-16, 1996) and at the annual meeting of the Teachers of English to Speakers of Other Languages (Orlando, FL, March 11-15, 1997). (ERIC Document Reproduction Service No. ED 41167)

Sadker, M. P., \& Sadker, D. M. (1980). Sexism in teacher-education texts. Harvard Educational Review, 50, 36-46.

Schmitz, B. (1975). Sexism in French language textbooks. In R. C. Lafayette (Ed.), The cultural revolution in foreign language teaching, (pp.199-300). Skokie, IL: National Textbook Co.

Siegal, M., \& Okamoto, S. (1996). Imagined worlds: Language, gender and sociocultural "norms" in Japanese language textbooks. In N. Warner, L. Ahlers, M. Bilmes, \& M. C. Oliver (Eds.), Gender and belief systems: Proceedings of the Fourth Berkeley Women and Language Conference (pp. 667-678). Berkeley, CA: University of California press.

Sims, R. L. (1997). Gender equity in management education: A content analysis of test bank questions. Journal of Education for Business, 72, 283-287.

Stern, R. H. (1976). Review article: Sexism in foreign language textbooks. Foreign Language Annals, 9, 294-2 99.

Sunderland, J. (1995). Exploring gender. Questions and implications for English language education. New York, Prentice Hall International Ltd.

Talansky, S. B. (1986). Sex role stereotyping in TEFL teaching materials. Perspectives, XI, 32-41.

Talbot, M. (1998). Language and gender. An introduction. Malden, MA: Polity Press.

Tietze, I. N., \& Davis, B. H. (1981). Sexism in texts in education administration. Paper presented at the annual meeting of the American Educational Research Association, Los Angeles.

Walford, G. (1981). Tracking down sexism in physics textbooks. Physics Education, 16, 261-265.

(Received April 26, 2001; revised January 14, 2002) 